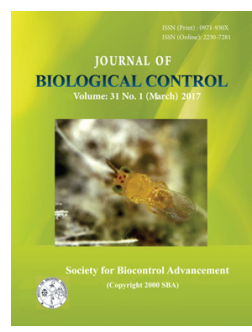

\title{
Formulation for optimizing Bacillus thuringiensis production
}

\author{
MONIKA TRIPATHI ${ }^{1,2}$ and GOVIND GUJAR ${ }^{1,3^{*}}$ \\ ${ }^{1}$ Division of Entomology, Indian Agricultural Research Institute (ICAR), New Delhi - 110012, Delhi, India \\ ${ }^{2}$ Department of Bioscience and Biotechnology, Banasthali University, Banasthali - 304022, Rajasthan India \\ ${ }^{3}$ South Asia Biotechnology Centre, New Delhi - 110091, Delhi, India \\ *Corresponding author E-mail: gtgujar@yahoo.com
}

\begin{abstract}
Bacillus thuringiensis Berliner, a gram positive aerobic bacterium, produces parasporal crystal (Cry) toxins that are highly specific and effective against insect species. During the course of isolation of native strains, B. thuringiensis AUG-5 was found the most effective with a wide range of activity against lepidopterans. Hence, different media were evaluated for its growth and development. Increase in concentration of the Luria Bertani [(LB), composed of casein, yeast extract and sodium chloride in 2:1:2 w/w)] medium in the fermentation broth from 1 to $2 \%$ increased colony forming unit (CFU), spore and also Cry1 Ac and Cry $2 \mathrm{Ab}$ toxin content. However, further increase of LB concentration to 3\% adversely affected bacterial growth and development. Addition of 1\% Wesson salt in 1\% LB broth significantly increased spore, CFU counts, and also that of Cry1Ac but not of Cry2Ab. Spore and CFU counts in media were positively correlated and cell mass negatively correlated with Cry1 Ac and Cry2Ab contents. Of all media substituting LB with agro products, medium consisting of $2 \%$ wheat flour, $2 \%$ soybean meal and $1 \%$ Wesson salt could be considered as an alternative to LB medium to achieve economy of largescale production costs. Spore-crystal complexes of Medium II and III were most toxic to the neonates of cotton bollworm, Helicoverpa armigera and tobacco caterpillar, Spodoptera litura at $10 \mu \mathrm{g} / \mathrm{g}$, and differed significantly from those of Medium LB-2X and LB-3X and Cry2Ab2. Cry1Ac was most toxic to H. armigera at $1 \mu \mathrm{g} / \mathrm{g}$ and less toxic to $S$. litura than Cry2Ab.
\end{abstract}

KEY WORDS: Agro byproducts, Bacillus thuringiensis, endotoxin production, culture media, insecticidal activity, Helicoverpa armigera, Spodoptera litura

(Article Chronicle: Received: 13-03-2017; Revised: 28-03-2017; Accepted: 31-03-2017)

\section{INTRODUCTION}

The use of synthetic insecticides to control insect pests started with the discovery of insecticidal properties of DDT in 1939. Since then, insecticides belonging to organophosphates, carbamates and many other chemical groups have been developed. In India, about 45,000 tons of pesticides are used annually, of which $50 \%$ are insecticides. These insecticides have been in use for a long time because of their stable residual action and toxicity to a wide spectrum of insect pests. However, there is a growing realization that some of these pesticides are disruptive to the environment. Further, their continued use leads to the development of resistance in the target species, thereby leading to their ineffectiveness and higher costs of crop protection by using higher doses and also costlier insecticides (Whalon et al., 2008, 2013).

Hence, the search for alternatives has led to the development of microbial biopesticides. The most promising microbial bioinsecticide to date is Bacillus thuringiensis (Entwistle et al., 1993; Navon, 2000; Bravo et al., 2011). More than 67 subspecies of $B$. thuringiensis have been characterized on the basis of flagellar H serovars (WHO, 1999). B. thuringiensis was first used for the field control of European corn borer in 1920s in France. And since then, many formulations have been developed commercially. Besides being effective and safe to the environment, $B$. thuringiensis sprayable formulations have a long shelf life (cf. Entwistle et al., 1993). About 13,000 tons or more of $B$. thuringiensis is produced annually all over the world for controlling insect pests of agricultural, forestry, medical and veterinary importance (WHO, 1999). The biopesticide market accounts for about 600 million US dollars, or $2 \%$ of the worldwide crop protection market, in which about $90 \%$ of all biopesticide sales involving products based on B. thuringiensis (Sanchis and Bourguet, 2008). Ramanujam et al. (2014) reported Bacillus thuringiensis, as most successfully utilized insect pathogen which is used extensively for management of certain lepidopteran pests. 
Bacillus thuringiensis is a gram-positive, spore-forming bacterium with entomopathogenic properties, belonging to the group Bacillus cereus (Schnepf et al., 1998; Bravo et al., 2011). It was first discovered in 1901 by Shigetane Ishiwata and re-described from the infected larvae of Mediterranean flour beetle in 1911 by Berliner (Nester et al., 2002; Bravo et al., 2011). The most important characteristic of this bacterium is the production of parasporal crystal (Cry) proteins which are insecticidal (Höfte and Whiteley, 1989; Schnepf et al., 1998). These crystals are composed of one or more toxin proteins, each with its specific range of activity against target pests. The Cry toxin proteins are classified on the basis of amino acid identity and homology eliminating need of bioassays, based upon report of the Bacillus thuringiensis delta-endotoxin nomenclature committee in 1993 (Crickmore et al., 1998, 2016). More than 318 Cry protein holotypes and approximately 827 Cry proteins have been identified on the basis of above criterion till last updated May 5, 2017 (http://www.lifesci.sussex.ac.uk/ home/Neil_Crickmore/Bt/).

Bacillus thuringiensis like any aerobic bacterium grows well on the Luria Bertani (LB) medium that contains casein, yeast extract and sodium chloride. Besides, other media, such as mannitol broth, nutrient yeast extract and super broth are also in use for bacterial production. The media for the production of highly effective biomass must contain source for amino acids, proteins, and also energy producing carbohydrates along with essential minerals. Morris et al. (1997) reported requirement of inorganic sources that functioned as constituents of macromolecules like protein, nucleic acid, enzymes for optimal growth of $B$. thuringiensis. Similarly, nitrogenous sources were found essential for optimal growth of B. thuringiensis (Johnson et al., 1994; Dhingra and Chaudhary, 2011). Carbohydrates, rich sources for energy like starch and molasses were also found to influence endotoxin production (Scherrer et al., 1973). Media containing fish meal, gruel and corn-steep liquor have also been successfully used for production of $B$. thuringiensis and Bacillus sphaericus (Salama et al., 1983; Kumar et al., 2000; Zouari et al., 2002). Media containing molasses, corn extract, and mineral salts (Moraes et al., 1981; Dregval et al., 1999), corn steep liquor, glucose, and mineral salts (Dregval et al., 2002), or potato, common sugar and chickpea (Poopathi and Kumar, 2003), cotton seed meal, soya meal, sunflower meal (Dhingra and Chaudhary, 2011) were all used for growth and production of B. thuringiensis. Powders of edible leguminous seeds were used as major sources of protein together with different combinations of soluble starch and/or sugarcane molasses as major carbohydrate sources. Similarly, soybean flour, groundnut cake powder and, wheat bran extract were separately used in large-scale production of $B$. thuringiensis bio-insecticide (Prabakaran and Balaraman, 2006). All these studies were aimed at using locally available cheaper media in place of costly sources, especially those rich in proteins like tryptone, peptone and casein. Most or all of these studies were restricted to biomass production rather than specific estimation of endotoxin production in the final fermentation product.

Bacillus thuringiensis strains have been isolated and characterized earlier from soil, phyllopane, dead insects, marshy soils, storage silos (Saravanan and Gujar, 2006; Meena et al., 2012). Of these, the most effective $B$. thuringiensis strain AUG-5 was found to have a wide range of high efficacy against lepidopteran larvae [Saravanan and Gujar (unpublished); Kalia et al., 2013]. It expresses two important toxins, Cry1 Ac and Cry2Ab in high concentrations. The objective of this study was to standardize the fermentation of $B$. thuringiensis strain AUG-5 in terms of endotoxin (Cry1 Ac and Cry2Ab) content, and also spore and colony forming units with the simple, locally available and costeffective liquid substrate media.

\section{MATERIALS AND METHODS}

\section{Site of Experiments}

All the experiments in this research work were carried out in the Division of Entomology, Indian Agricultural Research Institute (ICAR), at New Delhi (110012), India in the year 2012- 2013.

\section{Equipment}

A 3-liter vessel bench-top fermenter (Major Science: MS-F1-S-3L, USA) with autoclavable glass vessel was used for fermentation of B. thuringiensis in different fermentation media. The glass vessel could be autoclaved at $121{ }^{\circ} \mathrm{C}$ for $30 \mathrm{~min}$. The vessel had a condenser to circulate coolant at $10^{\circ} \mathrm{C}$, for cooling the fermentation medium, as per requirement of the fermentation cycle. The fermenter having orifice ring sparger, three adjustable Rushton-type impellers along with removable $316 \mathrm{~L}$ stainless steel baffles. In the fermentation system, the pre-filtered inlet air was passed through the sparger in to the bottom of the vessel, at a flow rate controlled by air flow controller. A temperature probe (platinum RTD probe: Pt-100) was provided to monitor temperature between 5 and $90{ }^{\circ} \mathrm{C}$. The dissolved oxygen (DO) and the $\mathrm{pH}$ of the fermentation medium were measured by a polarographic DO sensor and the $\mathrm{pH}$ sensor, respectively. Cell Density Sensor (TrueCell2 ${ }^{\mathrm{TM}}$; TXN CDS-AOI, Finesse solutions, USA) was used for observing the cell growth during the fermentation. All signals from the sensors were transferred to a RS-485 data acquisition system. 


\section{Bacterial Strain}

Bacillus thuringiensis isolate named as AUG-5 was isolated from the warehouse stored grain sample collected in 2002 from Delhi region, by using the sodium acetate selection procedure developed by Travers et al. (1987) and Saravanan and Gujar (2006). AUG-5 was characterized biochemically and with 16s DNA markers, and submitted to Gene Bank (Accession no. JX674043). It showed presence of cry $1 A$ and $c r y 2$ genes with specific primers (unpublished). The strain is maintained on nutrient agar slants at 4 ${ }^{\circ} \mathrm{C}$ along with sterile nutrient broth (Hi-Media) containing $20 \%$ glycerol at $-80{ }^{\circ} \mathrm{C}$ for further analysis.

\section{Media Preparation}

Sources of Agro-byproducts and their Production. Wheat (Triticum spp.) flour (Aashirvad, ITC limited, Mumbai, India), corn flour (Blue Bird Foods India Private Limited, Mumbai, India) and soybean (Glycine max) seed powder (Viraki Brothers, Navi Mumbai, India) were purchased from the grocery store, New Delhi, India. Cotton (Gossypium spp.) seed powder was obtained by grinding non-transgenic cotton (var. Pusa 8-6, IARI, New Delhi, India) seeds without seed coats.

Chemicals like Luria broth, Wesson salt and yeast autolysate were obtained from Himedia laboratories Pvt. Ltd., Mumbai. All other chemicals were locally procured from the reputed companies. Medium $L B-1 X(B O D)$ was composed of commercially available LB Broth [containing $1 \%$ casein enzymic hydrolysate, $0.5 \%$ yeast extract, $1 \%$ sodium chloride $(\mathrm{NaCl})]$. Fermentation was done by the use of incubator shaker (C24; New Brunswick Scientific, Edison, NJ, USA) at $37{ }^{\circ} \mathrm{C}$ and $200 \mathrm{rpm}$. Medium $L B-1 X$ was composed of LB broth (containing $1 \%$ casein enzymic hydrolysate, $0.5 \%$ yeast extract, $1 \% \mathrm{NaCl}$ ). For this medium, composition was same as LB-1X(BOD), but the fermentation was carried out in the 3 liter Fermenter with automatic monitoring of $\mathrm{DO}, \mathrm{pH}$, temperature and density. Medium $L B-2 X$ was prepared by doubling the quantity of LB broth (containing $2 \%$ casein enzymic hydrolysate, $1 \%$ yeast extract, $2 \% \mathrm{NaCl}$ ). Medium $L B-3 X$ was prepared by tripling the amount of LB broth (containing 3\% casein enzymic hydrolysate, $1.5 \%$ yeast extract, $3 \% \mathrm{NaCl}$ ). Medium I was composed of $2 \%$ wheat flour, $2 \%$ cotton seed powder, $1 \%$ Wesson salt mixture. Medium II was composed of $2 \%$ soybean seed powder, $2 \%$ wheat flour, $1 \%$ Wesson salt mixture. Medium III was composed of composed LB broth (1\% casein enzymatic hydrolysate, $1 \%$ yeast extract: $0.5 \% \mathrm{NaCl}$ ) and $1 \%$ Wesson salt mixture. Medium IV was composed of $1 \%$ corn flour, $0.2 \%$ casein (protein rich), $0.5 \%$ yeast autolysate, $0.2 \%$ peptone, $0.1 \%$ sucrose, $0.5 \% \mathrm{NaCl}$ and $0.4 \%$ Wesson salt mixture. Medium $V$ was composed of $1 \%$ corn flour, $1 \%$ soybean seed powder, $0.2 \%$ casein (protein rich), $0.5 \%$ yeast autolysate, $0.2 \%$ peptone, $0.1 \%$ sucrose, $0.5 \%$ $\mathrm{NaCl}$ and $0.4 \%$ Wesson salt mixture. Medium VI was composed $1 \%$ corn flour, $1 \%$ cotton seed powder, $0.2 \%$ casein (protein rich), $0.5 \%$ yeast autolysate, $0.2 \%$ peptone, $0.1 \%$ sucrose, $0.5 \% \mathrm{NaCl}$ and $0.4 \%$ Wesson salt mixture. $\mathrm{Me}$ dium VII was composed 1\% wheat flour, 1\% Soybean seed powder, $0.2 \%$ casein (protein rich), $0.5 \%$ yeast autolysate, $0.2 \%$ peptone, $0.1 \%$ sucrose, $0.5 \% \mathrm{NaCl}$ and $0.4 \%$ Wesson salt mixture.

Ingredients of media I, II, IV, V, VI and VII were soaked in distilled water for overnight at room temperature, and then homogenized in a laboratory grinder (if necessary) and filtered through a plastic strainer (100 mesh size). The clear supernatant was used. All culture media were adjusted $7.5 \pm 0.2 \mathrm{pH}$ and autoclaved at $121^{\circ} \mathrm{C}$ under $15 \mathrm{lb} / \mathrm{in}^{2}$ for 30 min (Morris et al., 1997; Shojaaddini et al., 2010).

\section{Seed Culture Preparation for Inoculation}

A loopful of bacteria from the mother culture was streaked onto a sterile nutrient agar plate, incubated at 37 ${ }^{\circ} \mathrm{C}$ for $24 \mathrm{~h}$. Seed culture was prepared by shaken flask technique. A single colony was transferred to each $250 \mathrm{ml}$ conical flask containing $50 \mathrm{ml}$ of LB broth and incubated in a shaker at $200 \mathrm{rpm}$ for $24 \mathrm{~h}$ at $37^{\circ} \mathrm{C}$ temperature.

\section{Fermentation}

Batch fermentation was carried out under the fully aseptic conditions to avoid cross contaminations during the whole run. A 10\% (vol/vol) inoculum was transferred from the Erlenmeyer flask to the fermenter vessel, which contained only 1 liter of the total medium. The fermentation was done at $37{ }^{\circ} \mathrm{C}, 300 \mathrm{rpm}$ and $\mathrm{pH}$ controlled automatically at 6.8-7.0 by the addition of $2 \mathrm{~N}$ sulphuric acid and $3 \mathrm{~N}$ sodium hydroxide as per needs for each cycle. The air flow rate was maintained at $0.5-1.5 \mathrm{vol} / \mathrm{vol}$. min (agitated at the $300 \mathrm{rpm}$ ) through sterile disk type air filter (Millipore; diameter: $45 \mathrm{~mm}$, pore size: $0.2 \mu \mathrm{m}$ ). It was manually controlled in parallel with agitation speed to maintain the DO level above $20 \%$ for the fermentation. No antifoam agent was added in the medium. In all cycles, samples were collected aseptically from the vessel at different intervals up to the end of the whole cycles. In all cycles peristaltic pumps were assigned for acid, base and sample recovery. Peristaltic pumps were connected through the silicon tubing (inner diameter: $3.2 \mathrm{~mm}$ ) and inlet and outlet speed was adjusted by making the changes in rpm of the pump (Range: $0-100$ rpm). For Medium LB-1X(BOD), fermentation was done in incubator shaker at $37{ }^{\circ} \mathrm{C}$ and $200 \mathrm{rpm}$. When the cultures were fully sporulated, they were harvested aseptically to prepare acetone precipitated spore-crystal complex. 


\section{Cell Mass Yield}

Fermentation process was stopped after reaching stationary phase in all media. The harvested culture was centrifuged at $8,000 \mathrm{rpm}$ at $4{ }^{\circ} \mathrm{C}$ for $10 \mathrm{~min}$. The supernatant was discarded and the pellet collected and re-suspended in $5 \%$ lactose solution at $1 / 10^{\text {th }}$ the original volume of the broth $(25 \mathrm{ml})$ and stirred continuously for $30 \mathrm{~min}$, then four volumes $(100 \mathrm{ml})$ of ice-cold acetone were added slowly and stirred for another $30 \mathrm{~min}$. The acetone precipitated powder containing spore-crystal complex was filtered through Whatman filter paper with a vacuum pump and dried overnight in a desiccator, then ground to fine powder, weighed and stored at $4{ }^{\circ} \mathrm{C}$ till use (Dulmage et al., 1970). Dry weight was calculated and expressed in grams per liter $(\mathrm{g} / \mathrm{l})$.

\section{Toxin Estimation with ELISA}

Cry1 Ac and Cry2Ab contents in spore-crystal complex of each isolate were estimated with their respective ELISA kits as per manufacturer's instructions (Quan-T ELISA, DesiGen, Jalna, India). The $2 \mathrm{mg}$ of spore-crystal complex of each product obtained by fermentation was weighed in an eppendorf tube, to which $200 \mu$ of the sample extraction buffer was mixed. In the case of liquid samples, $100 \mu \mathrm{l}$ of culture broth was mixed with $100 \mu$ of the sample extraction buffer. In both cases, the suspension was sonicated for $30 \mathrm{sec}$ at $50 \%$ duty cycle, chilled on ice for $10 \mathrm{~min}$ followed by $30 \mathrm{sec}$ sonication again. Then, suspension was vortexed and spinned for $15 \mathrm{~min}$ at $8,000 \mathrm{rpm}$, at $4{ }^{\circ} \mathrm{C}$. The pellet was discarded and the supernatant was proteolyzed $(3.5 \mu \mathrm{l}$ of trypsin was added to each $100 \mu$ sample). The mixture was then incubated for $30 \mathrm{~min}$ at $37^{\circ} \mathrm{C}$, after that, $2.5 \mu \mathrm{l}$ of $50 \mathrm{mM}$ PMSF per $100 \mu \mathrm{l}$ was added to each sample in the case of Cry1 Ac or Cry2Ab estimation and stored at $-80{ }^{\circ} \mathrm{C}$.

Positive and negative controls were prepared and divided in two halves. To each well, $150 \mu$ l of secondary antibody were added, followed by addition of selected medium samples per well for the quantification of Cry1Ac and Cry $2 \mathrm{Ab}$, respectively. Both plates were incubated at $37^{\circ} \mathrm{C}$ for one-and-half $\mathrm{h}$ in humid chamber. Then the plates were washed for 5 min twice with 1x wash buffer provided with kit, followed by addition of the tertiary antibody $(250 \mu \mathrm{l}$ /well). The plates were incubated at $37{ }^{\circ} \mathrm{C}$ for $45 \mathrm{~min}$ in humid chamber. After this incubation, $250 \mu$ l of freshly prepared $p$-nitrophenyl phosphate solution $(0.1 \mathrm{mg} / \mathrm{ml})$ were added to each well and the plates were incubated for $30 \mathrm{~min}$ at room temperature. Absorbance of the developed color formed was read at $405 \mathrm{~nm}$ after auto zero against control. The quantity of toxin produced by each isolate was calculated from the standard curve.

\section{Bioassays of Bacillus thuringiensis Spore-Crystal Com-} plex from Culturing on Different Media and Cry Toxins

The test insects viz., cotton bollworm Helicoverpa armigera and tobacco caterpillar, Spodoptera litura were reared in the laboratory on the chickpea based artificial diet. Adult female moths of $H$. armigera and $S$. litura laid eggs on cotton cloth and filter paper, respectively. The eggs were kept at room temperature under moist conditions of about $60 \%$ relative humidity $(\mathrm{RH})$ until their hatching. The method of bioassay was essentially as per Gujar et al. (2000). The spore-crystal complex of each selected medium was dissolved in the water to prepare stock solution of $1000 \mu \mathrm{g} /$ $\mathrm{ml}$ on the basis of total Cry toxin content. The final concentration of spore-crystal complex of B. thuringiensis of 10 $\mu \mathrm{g} / \mathrm{g}$ was made in $10 \mathrm{gm}$ artificial diet. An aliquot of about 3 gm diet was offered to 10 neonates of each test insect in a Petri plate for the period of $96 \mathrm{~h}$. Four treatments viz., Medium LB-2X, LB-3X, Medium II and III were used as their Cry2Ab/Cry1Ac ratios were 41, 22, 8.7 and 15.0, respectively. Besides, MVP II (19.7\% Cry1Ac) and the Bt corn leaf powder (6 mg Cry2Ab2/g) meant for resistance monitoring (from Monsanto Research Centre, Bangalore, India) were used as standards at final respective concentrations of $1 \mu \mathrm{g} / \mathrm{g}$ and $10 \mu \mathrm{g} / \mathrm{g}$, while control did not contain any toxin in the artificial diet. As many as 6 replicates for each treatment were kept. The mortality was recorded at $24 \mathrm{~h}$ interval until 7 days after treatment and analyzed for significant differences with analysis of variance using SAS software. The data of mortality on the $4^{\text {th }}$ and $7^{\text {th }}$ day of treatment were subjected to Statistical Analysis System (SAS) version 4.2 (SAS Institute Inc. Cary, USA) to determine significant differences with one-way analysis of variance (ANOVA). The significantly different means $(<0.05)$ were separated using Tukey's Studentized Range Test.

\section{Colony Forming Units (CFU)}

The samples were drawn at different intervals and analyzed for CFU to indicate presence of the viable cells. Total CFU was determined by spread plate method using nutrient agar plate. Samples were withdrawn at an interval of $24 \mathrm{~h}$, serially diluted with autoclaved distilled water, mixed on a vortex and $0.1 \mathrm{ml}$ of the each dilution above than $10^{-3}$ plated on nutrient agar plates in five replicates. Bacterial colonies were counted after overnight incubation at $37{ }^{\circ} \mathrm{C}$ using a digital colony counter, and then total CFU were calculated.

\section{Total Spore Counts}

The culture samples were collected in triplicates from each fermentation cycle. The number of individual spore was counted directly in a Neubauer counting chamber (Fein-Optik, Blankenburg, Germany) under a phase-contrast microscope at $400 \mathrm{x}$ magnification. 


\section{Growth of Bacillus thuringiensis in Selected Medium}

The growth of $B$. thuringiensis in the eleven different fermentation media was monitored with cell density sensor throughout fermentation at $650 \mathrm{~nm}$. Fermentation was terminated as soon as absorbance reached constant over 2-3 h.

\section{Microscopic Studies}

The presence of spore-crystal complex was recorded at various growth stages by phase contrast microscopy (DM 2500; LEICA Microsystems, Germany). The bacteria in the form of cells, spore-crystal complex in different fermentation media were harvested and suspended in water, and then smeared over the glass slide and viewed at 1000x magnification under oil emulsion in phase contrast microscopy to determine completion of spore formation.

\section{SDS Gel Electrophoresis of Toxin Proteins}

Bacillus thuringiensis spore-crystal complex obtained from the selected fermentation media was characterized using the sodium dodecyl sulphate-polyacrylamide gel electrophoresis (SDS-PAGE) as per Laemmli (1970). Four mg spore-crystal complex of the selected isolates as well as standard (reference medium) were solubilized in $400 \mu \mathrm{l}$ of solubilization buffer $(50 \mathrm{mM}$ sodium carbonate buffer, $10 \mathrm{mM}$ dithiothreitol, $\mathrm{pH} 10.5$ ) and sonication process was carried out twice at output 2 sec pulse, 50\% duty cycle, output control setting 8; timer on $2 \mathrm{~min}$ (LABSONIC L, Braun Biotech International, Germany). Solubilized samples were incubated at $37{ }^{\circ} \mathrm{C}$ for 3-4 h with slow shaking and after that centrifuged at 10,000 rpm for $10 \mathrm{~min}$; supernatant containing solubilized protoxin samples were transferred to new sterilized tubes. Solubilized protoxin were resuspended in equal amount of sample buffer $(0.6 \mathrm{ml}$ of

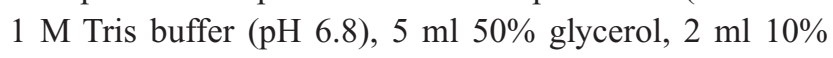

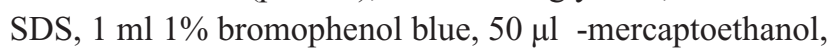
$0.9 \mathrm{ml}$ water) and boiled at $95-100^{\circ} \mathrm{C}$ for $5 \mathrm{~min}$. Ten $\mu \mathrm{l}$ of sample was then loaded and separated by SDS-PAGE using a continuous gel on $8 \%$ resolving gel and 5\% stacking gel. The gel was stained in staining solution $(0.25 \%$ Coomassie brilliant blue R250 in methanol: distilled water: acetic acid; 40: 50: 10) for $1 \mathrm{~h}$ and destained in destaining solution (methanol: distilled water: acetic acid; 40: 50: $10(\mathrm{v} / \mathrm{v})$ ) for $2 \mathrm{~h}$ with gentle shaking. The protein bands were visualized and photographed in a Gel Doc system (Alphaimager ${ }^{\mathrm{TM}}$ Documentation and analysis system).

\section{Statistical Data Analysis}

All data obtained from the determination of cell mass, delta-endotoxin production, CFU and spore counts were statistically analyzed by the SAS software using the oneway ANOVA test to compare the means. Correlation coef- ficients of cell mass, CFU and spore counts vis-à-vis Cry toxin contents were calculated to determine relationship using SAS software. The significantly different means $(<0.05)$ were separated using Tukey's Studentized Range Test.

\section{RESULTS AND DISCUSSION}

\section{Fermentation}

During fermentation, $\mathrm{pH}$ of media ranged from 6.8 to 7.2 , DO levels remained constant at $20 \%$, temperature at 37 ${ }^{\circ} \mathrm{C}$ and absorbance at $650 \mathrm{~nm}$ varied from 0.75 to 2.80 at the time of harvest depending upon medium and duration of fermentation. The sample culture collected from different fermentation medium was observed for vegetative cells, spores and crystal. Initially, until $24 \mathrm{~h}$ of culture growth, highest numbers of vegetative cells were recorded. Depending upon the fermentation medium, the spore-crystal complex occurred. Presence of maximal sporulation and also of the high absorbance at $650 \mathrm{~nm}$ was considered criteria of completion of run. Media LB-1X and LB-1X(BOD) were harvested after $72 \mathrm{~h}$, whereas, medium LB-2X, medium I, II, III, VII were harvested after $48 \mathrm{~h}$. In media LB-3X and medium $\mathrm{V}$ stationary phase achieved after 60 and $45 \mathrm{~h}$, respectively. The bacterial growth in Medium IV and medium VI reached stationary phase after 29 and 26 h, respectively.

\section{Cell Mass (Spore-Crystal Complex)}

The dry cell mass of AUG-5 obtained by different fermentation media varied. Out of all examined media, only the medium VI had the highest biomass production (5.44 $\mathrm{g} / \mathrm{l})$, as compared to the other media including the reference LB (Table 1). The biomass produced from medium $\mathrm{V}$ and VI was at par, which was followed by medium I, III and IV. Fermentation done in incubator shaker LB-1X(BOD) yielded the lowest biomass of $1.58 \pm 0.17 \mathrm{~g} / 1$.

\section{Cry1Ac and Cry2Ab Toxin Quantification}

In all fermentation media, Cry1Ac content of the harvested spore-crystal complex ranged from 5.6 to $139.3 \mathrm{ng} /$ mg powder. Similarly, Cry $2 \mathrm{Ab}$ content ranged from 0 to $4235 \mathrm{ng} / \mathrm{mg}$ powder (Table 2). Cry1 Ac estimation was also done for the liquid samples from the fermenter collected at $24 \mathrm{~h}$. It ranged from 28.2 to $1120 \mathrm{ng} / \mathrm{ml}$ at $24 \mathrm{~h}$, whereas the range was from 10.4 to $1500.6 \mathrm{ng} / \mathrm{ml}$ at $48 \mathrm{~h}$ of fermentation in different media. Cry2 $\mathrm{Ab}$ toxin also varied from 0 to $5778.0 \mathrm{ng} / \mathrm{ml}$ at $24 \mathrm{~h}$ and 0 to $7205.2 \mathrm{ng} / \mathrm{ml}$ at $48 \mathrm{~h}$ of fermentation in different media (data not presented). Ratio of Cry2Ab/Cry1Ac differed from less than 0 to as high as 41.14 depending upon the medium used for culturing bacterium. In spore-crystal complexes from medium VI and VII, only Cry1Ac was found to be $12.92 \mathrm{ng} / \mathrm{mg}$ and $5.62 \mathrm{ng} / \mathrm{mg}$, respectively. 
Table 1. Details of fermentation process and production of spore-crystal complex of Bacillus thuringiensis in different fermentation media

\begin{tabular}{|c|c|c|c|c|}
\hline Medium Annotation & $\begin{array}{l}\text { Fermentation } \\
\text { method }\end{array}$ & $\begin{array}{l}\text { Incubation } \\
\text { Time (h) }\end{array}$ & Medium Composition & $\begin{array}{l}\text { Mass }(g / 1)^{1} \\
\pm \mathrm{SE}\end{array}$ \\
\hline LB-1X(BOD) & Incubator shaker & $72 \mathrm{~h}$ & $\begin{array}{l}1 \% \text { Casein enzymatic hydrolysate, } 0.5 \% \text { Yeast } \\
\text { extract, } 1 \% \mathrm{NaCl}\end{array}$ & $1.58 \pm 0.17^{\mathrm{f}}$ \\
\hline LB-1X & Fermenter & $72 \mathrm{~h}$ & $\begin{array}{l}1 \% \text { Casein enzymatic hydrolysate, } 0.5 \% \text { Yeast } \\
\text { extract, } 1 \% \mathrm{NaCl}\end{array}$ & $2.52 \pm 0.13^{\mathrm{e}}$ \\
\hline LB-2X & Fermenter & $48 \mathrm{~h}$ & $\begin{array}{l}2 \% \text { Casein enzymatic hydrolysate, } 1 \% \text { Yeast } \\
\text { extract, } 2 \% \mathrm{NaCl}\end{array}$ & $2.48 \pm 0.03^{\mathrm{e}}$ \\
\hline LB-3X & Fermenter & $60 \mathrm{~h}$ & $\begin{array}{l}3 \% \text { Casein enzymatic hydrolysate, } 1.5 \% \text { Yeast } \\
\text { extract, } 3 \% \mathrm{NaCl}\end{array}$ & $2.66 \pm 0.04^{\mathrm{e}}$ \\
\hline Medium I & Fermenter & $48 \mathrm{~h}$ & $\begin{array}{l}2 \% \text { Wheat flour, } 2 \% \text { Cotton seed powder, } 1 \% \\
\text { Wesson salt mixture }\end{array}$ & $4.16 \pm 0.04^{c}$ \\
\hline Medium II & Fermenter & $48 \mathrm{~h}$ & $\begin{array}{l}2 \% \text { Wheat flour, } 2 \% \text { Soybean meal, } 1 \% \text { Wesson } \\
\text { salt mixture }\end{array}$ & $3.14 \pm 0.01^{\mathrm{d}}$ \\
\hline Medium III & Fermenter & $48 \mathrm{~h}$ & $\begin{array}{l}1 \% \text { Casein enzymatic hydrolysate, } 0.5 \% \text { Yeast } \\
\text { extract, } 0.5 \% \mathrm{NaCl} \text { ) and } 1 \% \text { Wesson salt mixture }\end{array}$ & $4.00 \pm 0.01^{\mathrm{c}}$ \\
\hline Medium IV & Fermenter & $29 \mathrm{~h}$ & $\begin{array}{l}1 \% \text { Corn flour, } 0.2 \% \text { Casein (protein rich), } 0.5 \% \\
\text { Yeast autolysate, } 0.2 \% \text { Peptone, } 0.1 \% \text { Sucrose, } \\
0.5 \% \mathrm{NaCl} \text { and } 0.4 \% \text { Wesson salt mixture }\end{array}$ & $4.02 \pm 0.01^{\mathrm{c}}$ \\
\hline Medium V & Fermenter & $45 \mathrm{~h}$ & $\begin{array}{l}1 \% \text { Corn flour, } 1 \% \text { Soybean meal, } 0.2 \% \text { Casein } \\
\text { (protein rich), } 0.5 \% \text { Yeast autolysate, } 0.2 \% \\
\text { Peptone, } 0.1 \% \text { Sucrose, } 0.5 \% \mathrm{NaCl} \text { and } 0.4 \% \\
\text { Wesson salt mixture }\end{array}$ & $4.60 \pm 0.06^{\mathrm{b}}$ \\
\hline Medium VI & Fermenter & $26 \mathrm{~h}$ & $\begin{array}{l}1 \% \text { Corn flour, } 1 \% \text { Cotton seed powder, } 0.2 \% \\
\text { Casein (protein rich), } 0.5 \% \text { Yeast autolysate, } \\
0.2 \% \text { Peptone, } 0.1 \% \text { Sucrose, } 0.5 \% \mathrm{NaCl} \text { and } \\
0.4 \% \text { Wesson salt mixture }\end{array}$ & $5.44 \pm 0.04^{\mathrm{a}}$ \\
\hline Medium VII & Fermenter & $48 \mathrm{~h}$ & $\begin{array}{l}1 \% \text { Wheat flour, } 1 \% \text { Soybean meal, } 0.2 \% \text { Casein } \\
\text { (protein rich), } 0.5 \% \text { Yeast autolysate, } 0.2 \% \\
\text { Peptone, } 0.1 \% \text { Sucrose, } 0.5 \% \mathrm{NaCl} \text { and } 0.4 \% \\
\text { Wesson salt mixture }\end{array}$ & $4.66 \pm 0.11^{b}$ \\
\hline
\end{tabular}

${ }^{1}$ Mean and standard error (SE) were generated by the SAS System; using the one-way analysis of variance (ANOVA), Tukey's Studentized Range (HSD) Test ( Means followed by same letters within a column are not significantly different $[\mathrm{F}=229.57$; $\mathrm{df}=10 ; P<0.0001]$

Table 2. Spore, colony forming unit (CFU) count and quantitative estimation of Cry1Ac and Cry2Ab toxin produced by Bacillus thuringiensis in different fermentation media

\begin{tabular}{|c|c|c|c|c|c|c|c|}
\hline $\begin{array}{l}\text { Medium } \\
\text { Annotation }\end{array}$ & $\begin{array}{l}\text { Fermentation } \\
\text { equipment }\end{array}$ & $\begin{array}{l}\text { Incubation } \\
\text { Time (h) }\end{array}$ & $\begin{array}{l}\text { Spore } / \mathrm{ml}^{1} \\
\pm \mathrm{SE}\end{array}$ & $\begin{array}{l}\mathrm{CFU} / \mathrm{ml}^{1} \\
\pm \mathrm{SE}\end{array}$ & $\begin{array}{l}\text { Cry1Ac(ng/ } \\
\mathrm{mg})^{1} \\
\pm \mathrm{SE}\end{array}$ & $\begin{array}{l}\text { Cry } 2 \mathrm{Ab} \\
(\mathrm{ng} / \mathrm{mg})^{1} \\
\pm \mathrm{SE}\end{array}$ & $\begin{array}{l}\text { Cry2Ab/ } \\
\text { Cry1Ac } \\
\text { Ratio (ng/mg) }\end{array}$ \\
\hline $\begin{array}{l}\text { LB-1X } \\
\text { (BOD) }\end{array}$ & $\begin{array}{l}\text { Incubator } \\
\text { shaker }\end{array}$ & $72 \mathrm{~h}$ & $9.55 \pm 0.20 \times 10^{8(\mathrm{f})}$ & $7.33 \pm 0.33 \times 10^{8(\mathrm{f})}$ & $83.69 \pm 1.25^{\mathrm{c}}$ & $2607.50 \pm 1.23^{\mathrm{c}}$ & 31.16 \\
\hline LB-1X & Fermenter & $72 \mathrm{~h}$ & $13.53 \pm 0.49 \times 10^{8(\mathrm{e})}$ & $12.67 \pm 0.33 \times 10^{8(\mathrm{e})}$ & $108.88 \pm 0.99^{b}$ & $3610.00 \pm 0.99^{b}$ & 33.16 \\
\hline LB-2X & Fermenter & $48 \mathrm{~h}$ & $27.67 \pm 0.60 \times 10^{8(\mathrm{c})}$ & $24.33 \pm 0.33 \times 10^{8(\mathrm{c})}$ & $102.93 \pm 2.99^{b}$ & $4235.00 \pm 175.99^{\mathrm{a}}$ & 41.14 \\
\hline LB-3X & Fermenter & $60 \mathrm{~h}$ & $9.98 \pm 0.02 \times 10^{8(\mathrm{f})}$ & $8.67 \pm 0.67 \times 10^{8(f)}$ & $60.11 \pm 1.02^{\mathrm{e}}$ & $1340.00 \pm 130^{\mathrm{e}}$ & 22.29 \\
\hline Medium I & Fermenter & $48 \mathrm{~h}$ & $4.03 \pm 0.04 \times 10^{8(\mathrm{hi})}$ & $3.43 \pm 0.08 \times 10^{8(\mathrm{~g})}$ & $32.99 \pm 0.38^{\mathrm{f}}$ & $565.34 \pm 35.83^{f}$ & 17.14 \\
\hline Medium II & Fermenter & $48 \mathrm{~h}$ & $6.37 \pm 0.04 \times 10^{8(\mathrm{~g})}$ & $4.93 \pm 0.23 \times 10^{8(\mathrm{~g})}$ & $83.34 \pm 1.82^{\mathrm{c}}$ & $726.49 \pm 15.07^{\mathrm{f}}$ & 8.72 \\
\hline Medium III & Fermenter & $48 \mathrm{~h}$ & $87.33 \pm 0.17 \times 10^{8(a)}$ & $84.67 \pm 0.88 \times 10^{8 \text { (a) }}$ & $139.31 \pm 0.71^{\mathrm{a}}$ & $2082.09 \pm 5.79^{\mathrm{d}}$ & 14.95 \\
\hline Medium IV & Fermenter & $29 \mathrm{~h}$ & $17.75 \pm 0.03 \times 10^{8(\mathrm{~d})}$ & $16.00 \pm 0.58 \times 10^{8(\mathrm{~d})}$ & $69.11 \pm 1.98^{\mathrm{d}}$ & $1545.58 \pm 40.95^{\mathrm{e}}$ & 22.36 \\
\hline Medium V & Fermenter & $45 \mathrm{~h}$ & $52.67 \pm 0.44 \times 10^{8(b)}$ & $52.00 \pm 0.58 \times 10^{8(b)}$ & $90.52 \pm 1.25^{\mathrm{c}}$ & $1556.38 \pm 68.74^{\mathrm{e}}$ & 17.19 \\
\hline Medium VI & Fermenter & $26 \mathrm{~h}$ & $3.20 \pm 0.03 \times 10^{8(\mathrm{i})}$ & $2.77 \pm 0.12 \times 10^{8(\mathrm{~g})}$ & $12.92 \pm 0.87^{\mathrm{g}}$ & $0.00 \pm 0.52^{\mathrm{g}}$ & 0.00 \\
\hline Medium VII & Fermenter & $48 \mathrm{~h}$ & $5.28 \pm 0.18 \times 10^{8(\mathrm{gh})}$ & $4.30 \pm 0.30 \times 10^{8(\mathrm{~g})}$ & $5.62 \pm 1.37^{\mathrm{g}}$ & $0.00 \pm 0.80^{\mathrm{g}}$ & 0.00 \\
\hline$p$ value & -- & -- & $<0.0001$ & $<0.0001$ & $<0.0001$ & $<0.0001$ & -- \\
\hline$F$ & -- & -- & 8325.13 & 3047.73 & 761.18 & 378.4 & -- \\
\hline$d f$ & -- & -- & 10 & 10 & 10 & 10 & -- \\
\hline
\end{tabular}

${ }^{1}$ Mean and Standard error (SE); Figures followed by different letters within a column are significantly different as per Tukey's Studentized Range (HSD) test. 
Efficacy of Spore-Crystal Complex of Bacillus thuringiensis against Helicoverpa armigera and Spodoptera litura

MVPII Cry1 Ac was highly effective against $H$. armigera $(100 \%$ mortality) even at $1 \mu \mathrm{g} / \mathrm{g}$, while Cry $2 \mathrm{Ab}$ caused a maximum mortality of $46.7 \%, 4$ days after treatment. All other treatments at $10 \mu \mathrm{g} / \mathrm{g}$ caused $100 \%$ mortality within 2 days. It seemed that low Cry $2 \mathrm{Ab} / \mathrm{Cry} 1 \mathrm{Ac}$ ratio (8.7 in Medium II) caused the highest mortality (ca. 63.3\%) of $\mathrm{H}$. armigera larvae one day after treatment as compared to other treatments arising out of other media. In the case of S. litu$\mathrm{ra}$, Cry $2 \mathrm{Ab} 2$ caused maximal mortality of $60 \%$, while the spore-crystal complex of Media LB-2X and LB-3X caused about $80 \%$ at par, and Media II and III $100 \%$ mortality each at $10 \mu \mathrm{g} / \mathrm{g}$ concentration, 7 days after treatment. Further, $S$. litura was less susceptible to the spore-crystal complex than H. armigera (Table 3).

\section{Colony Forming Units (CFU)}

The cell growth of AUG-5 isolate in all fermentation media was determined by CFU count method (Table 2). A maximum viable cell count of $84.67 \pm 0.88 \times 10^{8}$ $\mathrm{CFU} / \mathrm{ml}$ was observed in Medium III, followed by medium V $\left(52.00 \pm 0.58 \times 10^{8} \mathrm{CFU} / \mathrm{ml}\right)$, then Medium LB-1X $\left(12.67 \pm 0.33 \times 10^{8} \mathrm{CFU} / \mathrm{ml}\right)$, and finally the Medium LB$1 \mathrm{X}$ (BOD) $\left(7.33 \pm 0.33 \times 10^{8} \mathrm{CFU} / \mathrm{ml}\right)$. In the Medium VI, lowest CFU count $2.77 \pm 0.12 \times 10^{8} \mathrm{CFU} / \mathrm{ml}$ was observed. Similarly, in Medium I, it was $3.43 \pm 0.08 \times 10^{8} \mathrm{CFU} / \mathrm{ml}$, and in Medium II, $4.93 \pm 0.23 \times 10^{8} \mathrm{CFU} / \mathrm{ml}$.

\section{Microscopic Examination and Total Spore Counts}

Microscopic examination of cells, spore and crystals under oil at 1000x magnification revealed presence of spore and crystals as cells crossed stationary phase. Later, spores-crystal complexes burst out and few cells were seen at the fag end of sporulation. Spore count produced by the different fermentation media varied. The spore count of Medium III was the highest $\left(87.33 \pm 0.17 \times 10^{8} / \mathrm{ml}\right)$ than the Medium VI (3.20 $\left.\pm 0.03 \times 10^{8} / \mathrm{ml}\right)$. In media LB-1X(BOD), LB-1X, LB-2X, and LB-3X, observed spore counts were $9.55 \pm 0.20 \times 10^{8} / \mathrm{ml}, 13.53 \pm 0.49 \times 10^{8} / \mathrm{ml}, 27.67 \pm 0.60 \times 10^{8}$ $/ \mathrm{ml}, 9.98 \pm 0.02 \times 10^{8} / \mathrm{ml}$, respectively (Table 2 ).

Cry1Ac contents in the spore-crystal complexes were positively correlated with CFU counts $\left(\mathrm{r}^{2}, 0.46\right)$ and spore counts $\left(r^{2}, 0.47\right)$ of nine media, and negatively correlated with cell mass $\left(\mathrm{r}^{2}, 0.26\right)$ of eleven media (Fig. 1). Similarly, $\mathrm{Cry} 2 \mathrm{Ab}$ contents in the spore-crystal complexes were positively correlated with the CFU counts $\left(\mathrm{r}^{2}, 0.68\right)$ and spore counts $\left(r^{2}, 0.68\right)$ of nine media, and negatively correlated with cell mass $\left(r^{2}, 0.51\right)$ of eleven media (Fig.1).

\section{SDS-PAGE of Cry Toxin}

The protein profile of endotoxin complex of the bacterial isolate from selected fermentation media revealed presence of major protein bands of about 130,63-75 and 48 $\mathrm{kDa}$ (Fig. 2). These proteins may belong to Cry1 and Cry2 protoxins and their activation products. The protein of 29 $\mathrm{kDa}$ may correspond to the cytolytic toxin.

One of the most important aspects of fermentation is sourcing for readily available relatively cheap agro byproducts. These sources provide necessary carbon, nitrogen, and other essential minerals for the vegetative cells, spores and crystal toxin growth. Various agricultural nitrogen sources like defatted and expeller cakes of mustard Brassica, cottonseed, groundnut, corn steep liquor have been used to develop low-cost fermentation media in batch culture process (Johnson et al., 1994). High spore yield was reported with a medium containing cheese whey, soybean milk and mo-

Table 3. Toxicity of spore-crystal complex of Bacillus thuringiensis in different fermentation media at $10 \mu \mathrm{g} / \mathrm{g}$ except Cry1Ac at $1 \mu \mathrm{g} / \mathrm{g}$ to the neonates of Helicoverpa armigera and Spodoptera litura

\begin{tabular}{|c|c|c|c|c|c|c|c|}
\hline \multirow{3}{*}{$\begin{array}{l}\text { Fermenta-tion } \\
\text { product }\end{array}$} & \multicolumn{7}{|c|}{ Mean mortality $(\%)^{1} \pm \mathrm{SE}$} \\
\hline & \multicolumn{4}{|c|}{ H. armigera } & \multicolumn{3}{|l|}{ S. litura } \\
\hline & 1 day & 2 day & 3 day & 4 day & 1 day & 4 day & 7 day \\
\hline LB-2X & $48.33 \pm 4.77^{b}$ & $100.00 \pm 0.00^{\mathrm{a}}$ & $100.00 \pm 0.00^{\mathrm{a}}$ & $100.00 \pm 0.00^{\mathrm{a}}$ & $25.00 \pm 2.24^{\mathrm{a}}$ & $75.00 \pm 4.28^{\mathrm{b}}$ & $81.67 \pm 4.01^{\mathrm{b}}$ \\
\hline LB-3X & $43.33 \pm 4.22^{\mathrm{b}}$ & $100.00 \pm 0.00^{\mathrm{a}}$ & $100.00 \pm 0.00^{\mathrm{a}}$ & $100.00 \pm 0.00^{\mathrm{a}}$ & $25.00 \pm 2.24^{\mathrm{a}}$ & $71.67 \pm 3.07^{\mathrm{b}}$ & $80.00 \pm 2.58^{\mathrm{b}}$ \\
\hline Medium-II & $63.33 \pm 3.33^{\mathrm{a}}$ & $100.00 \pm 0.00^{\mathrm{a}}$ & $100.00 \pm 0.00^{\mathrm{a}}$ & $100.00 \pm 0.00^{\mathrm{a}}$ & $36.67 \pm 4.94^{\mathrm{a}}$ & $100.00 \pm 0.00^{\mathrm{a}}$ & $100.00 \pm 0.00^{\mathrm{a}}$ \\
\hline Medium-III & $55.00 \pm 4.28^{\mathrm{ab}}$ & $100.00 \pm 0.00^{\mathrm{a}}$ & $100.00 \pm 0.00^{\mathrm{a}}$ & $100.00 \pm 0.00^{\mathrm{a}}$ & $26.67 \pm 4.94^{\mathrm{a}}$ & $100.00 \pm 0.00^{\mathrm{a}}$ & $100.00 \pm 0.00^{\mathrm{a}}$ \\
\hline Cry1Ac & $13.33 \pm 2.11^{\mathrm{cd}}$ & $33.33 \pm 4.22^{b}$ & $68.33 \pm 3.07^{\mathrm{b}}$ & $100.00 \pm 0.00^{\mathrm{a}}$ & $5.00 \pm 2.24^{\mathrm{b}}$ & $26.67 \pm 2.11^{\mathrm{d}}$ & $31.67 \pm 1.67^{\mathrm{d}}$ \\
\hline Cry2Ab2 & $25.00 \pm 2.24^{\mathrm{c}}$ & $40.00 \pm 3.65^{b}$ & $46.67 \pm 4.22^{c}$ & $46.67 \pm 4.22^{b}$ & $6.67 \pm 4.94^{b}$ & $51.67 \pm 4.01^{\mathrm{c}}$ & $60.00 \pm 3.65^{\mathrm{c}}$ \\
\hline$p$ value & $<0.0001$ & $<0.0001$ & $<0.0001$ & $<0.0001$ & $<0.0001$ & $<0.0001$ & $<0.0001$ \\
\hline$F$ & 47.62 & 401.43 & 383.91 & 622.50 & 15.09 & 201.26 & 249.40 \\
\hline$d f$ & 6 & 6 & 6 & 6 & 6 & 6 & 6 \\
\hline
\end{tabular}

${ }^{1}$ Mean and standard error (SE) were generated by the SAS System; using the one-way analysis of variance (ANOVA), Tukey's Studentized Range (HSD) Test (Means followed by same letters within a column are not significantly different). 

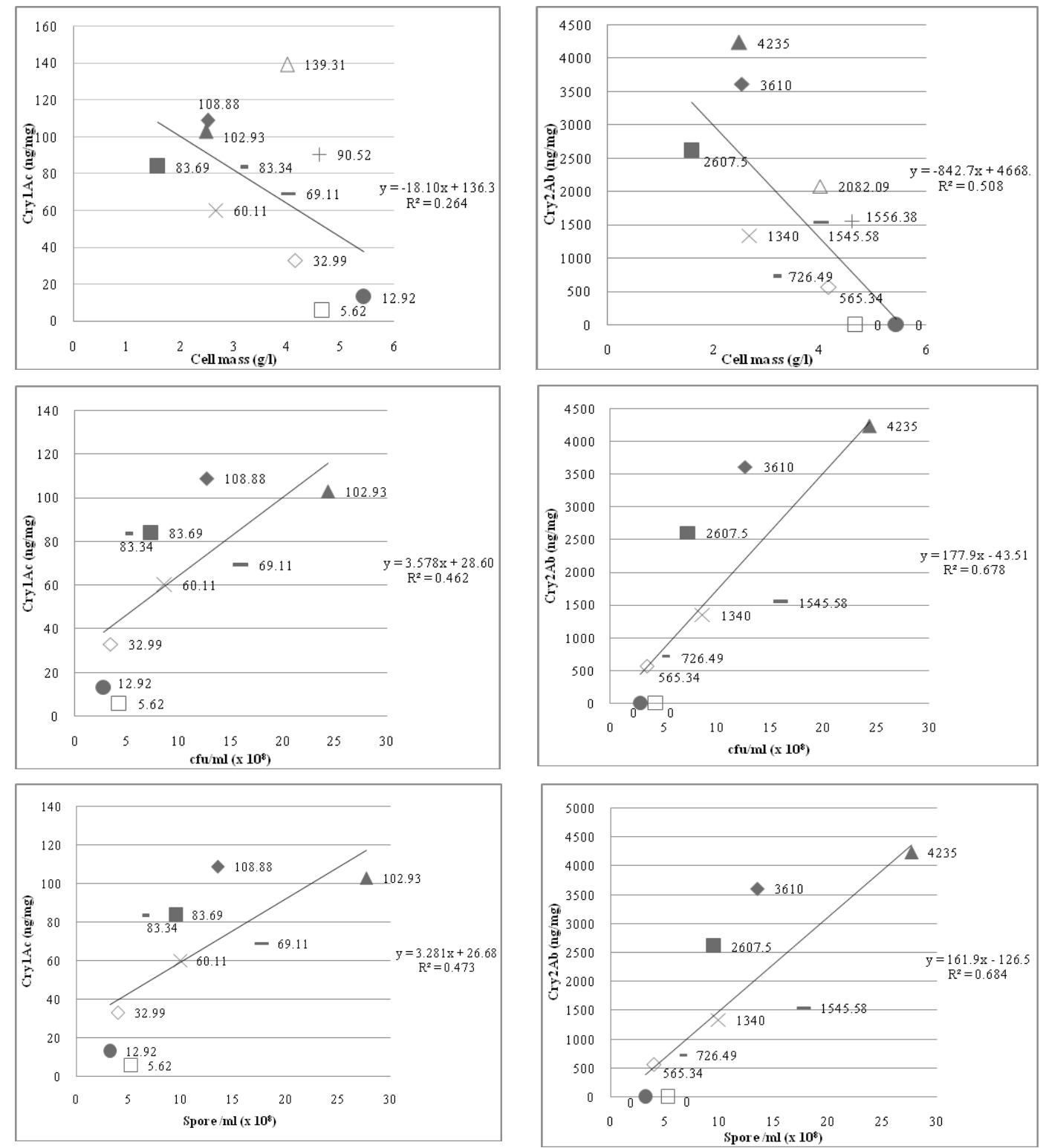

Fig. 1. Analysis of cell mass, CFU and spore count estimated in crystal-spore complex of Bacillus thuringiensis strain AUG-5 in different fermentation media $\backsim-\mathrm{LB}-1 \mathrm{X}$ (BOD), $\downarrow-\mathrm{LB}-1 \mathrm{X}, \mathbf{\Delta - L B}-\mathbf{2 X}$, ×-LB-3X, $\diamond$-Medium I, --Medium II, $\Delta$-Medium III, --Medium IV, +-Medium V, •-Medium VI, $\square-$ Medium VII (data with extremely high values of spore and CFU counts as in Media III and V removed).

lasses (Alves et al., 1997). B. thuringiensis also requires, for optimal growth, a variety of macro and microelements which function as co-factors of numerous enzyme reactions (Sarrafzadeh et al., 2005). B. thuringiensis isolates showed maximum growth after $48 \mathrm{~h}\left(1.3 \times 10^{10}\right.$ cells $\left./ \mathrm{ml}\right)$ when 10 $\mathrm{g} / \mathrm{l}$ of cottonseed meal was added in the production media (Harish, 2006). Valicente et al. (2010) developed a medium with $1.4 \times 10^{9}$ spores $/ \mathrm{ml}$ after $96 \mathrm{~h}$ of fermentation and was toxic to the Spodoptera frugiperda first instar larvae.

Cotton seed meal, chickpea, defatted groundnut cake, gram flour, soybean, defatted soya flour and corn gluten meal were found to be the most efficient substrates for the production of B. thuringiensis biomass (Morris et al., 1997; Poopathi and Kumar, 2003), whereas for the production of B. sphaericus strain egg yolk provided a low cost yet efficient medium (Yadav et al., 2011).

Bacteria in the incubator shaker grew at a slower rate than those in the automated fermenter, as the former was without $\mathrm{pH}$ and $\mathrm{DO}$ controls. Increase in oxygen concentration was shown to enhance bacterial growth in the medium containing molasses and corn steep liquor (Moraes et al., 1981). 
Usually, $\mathrm{pH}$ pattern of fermentation medium of $B$. thuringiensis in the incubator-shaker (without automatic $\mathrm{pH}$ control) showed a definite trend. Initially, $\mathrm{pH}$ dropped slightly followed by increase even up to 9.0 on the completion of fermentation. In the case of fermenter, the $\mathrm{pH}$ of medium was auto-controlled and maintained at 6.8 to 7.0 with a little quantity of alkali and acid to ensure fast bacterial growth as reflected by spore-crystal mass in fermenter rather than in the incubator-shaker. Similar observations were also recorded by Abdel-Hameed et al. (1991).

Increase in concentration of LB medium from 1 to $2 \%$ in fermentation broth enhanced spore and CFU counts; and also of Cry $2 \mathrm{Ab}$ content; but not of Cry1 Ac content, but further increase of LB concentration to $3 \%$ adversely affected spore, $\mathrm{CFU}$ and toxin contents. Addition of Wesson salt was found to enhance cell mass as well as endotoxin (Cry1Ac and Cry2Ab) production as seen from AUG-5(6) vis-àvis Medium III. Dulmage (1971) reported that endotoxin production by $B$. thuringiensis varied over the medium in which was grown. Khodair et al. (2008) reported differences in the production of cell mass based upon the media used for culturing $B$. thuringiensis and also showed wide variation in the mortality of cotton leafworm, Spodoptera littoralis on the basis of differences in media used. Positive relationship between Cry toxin contents and CFU or spore counts and the negative relationship with cell mass suggest that the CFU and spore counts are also useful criteria. It is also likely that negative relationship with cell mass is indicative of presence of unutilizable nutrients in the cell mass at the end of fermentation. This is in contrast with cell mass criterion for production used earlier. All other agrobased media except Medium VI and VII were found to support growth and development of $B$. thuringiensis, but not as efficiently as LB medium. Further, Medium VI and VII were quite deficient in supporting bacterial growth and Cry toxin production. These studies show that nutritional constituents should be qualitatively as well as quantitatively balanced for optimal bacterial growth. Further, fermentation media seemed to influence the relative proportion of two Cry toxins in the final product. The toxicity of spore-crystal complex from different media caused the fastest and the highest mortality of $H$. armigera at $10 \mu \mathrm{g} / \mathrm{g}$ which suggested innate synergistic susceptibility of test insect to the mixture of Cry toxins. It is well known that Cryl Ac is highly toxic to $H$. armigera than Cry2Ab. Although initial response of larvae of $S$. litura over first four days to the toxicity of Cry2Ab and spore-crystal complex of various media was slow and varied, Media II and III caused 100\% mortality of larvae of S. litura 7 days after treatment. As reported in the present study, Cry2Ab is known to be more toxic to $S$. litura than Cry1Ac while Cry1Ac is more toxic to H. armigera than Cry2Ab (Lu et al., 2013). The spore-crystal complexes of media with higher ratios of Cry2Ab/Cry1Ac were expected to be more toxic to $S$. litura than others, but were not discriminatory in the present case. However, spore-crystal complexes of Media II and III with Cry2Ab/Cry1Ac ratio of 15 or less were more toxic to H. armigera than those with higher ratios. It appeared that hereto, mixtures of Cry $1 \mathrm{Ac}$ and Cry $2 \mathrm{Ab}$ was more toxic than Cry1 Ac or Cry $2 \mathrm{Ab}$ to neonates of S. litura. The higher toxicity of Medium II may also be attributed to the presence of toxin proteins as these are reported in soybean (Hwang et al., 1978; Oliveira et al., 2010).

These studies showed that Medium II consisting of 2\% wheat flour, $2 \%$ soybean meal and $1 \%$ Wesson salt could prove to be good alternative to LB medium in terms of economy of input cost if production is taken upon the large scale.

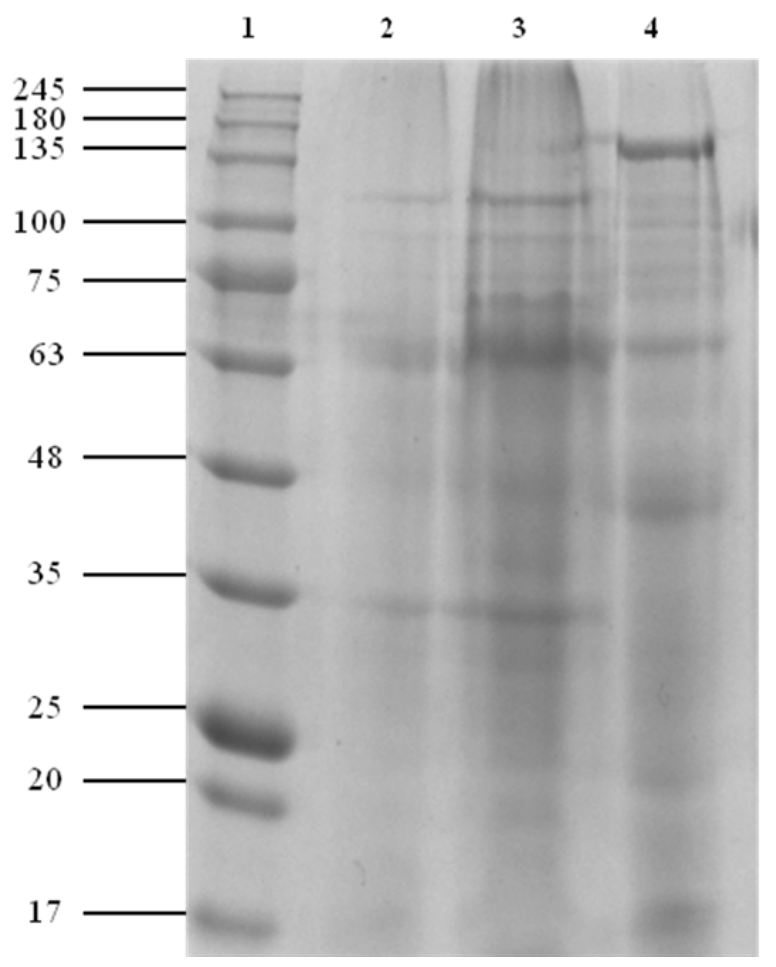

Fig. 2. SDS-PAGE analysis of acetone precipitated sporecrystal complex of best selected medium and reference Bacillus thuringiensis strain. From left to right: (1) BLUeye prestained protein marker (GeneDirex $\left.{ }^{\circledR}\right): 245,180,135,100,75,63,48,35,25,20,17$, $11 \mathrm{kDa}$, (2) Crude protein of Bacillus thuringiensisAUG-5 in LB-2X medium, (3) Crude protein of Bacillus thuringiensis-AUG-5 in Medium-III, (4) HD-1 (Bacillus thuringiensis spp. kurstaki).

\section{ACKNOWLEDGEMENT}

Thanks are due to the Director, Indian Agricultural Research Institute, New Delhi for providing infrastructural facilities. We are also thankful to National Agricultural In- 
novation Project (NAIP), Indian Council of Agricultural Research, New Delhi, for providing funding and fellowship to fulfill all necessity while research work. Author is also thankful to Prof. Aditya Shastri, Vice-Chancellor, Banasthali University and Prof. Vinay Sharma, Head, Department Bioscience \& Biotechnology, Banasthali University, Banasthali, Rajasthan.

\section{REFERENCES}

Abdel- Hameed A, Carlberg G, El-Tayeb OM. 1991. Studies on the Bacillus thuringiensis $\mathrm{H}-14$ strains isolated in Egypt-IV Characterization of fermentation conditions for $\delta$ endotoxin production. World J Micro Biot. 7: $231-236$

Alves LFA, Alves SB, Capalbo DMF. 1997. Selection of Agroindustrial by-products as components of media used for production of Bacillus thuringiensis var. kurstaki Berliner. An Soc Entomol Bras. 26(2): 379382 .

Bravo A, Likitvivatanavong S, Gill SS, Soberon M. 2011. Bacillus thuringiensis: A story of a successful bioinsecticide. Insect Biochem Mol Biol. 41(7): 423-431.

Crickmore N, Zeigler DR, Feitelson J, Schnepf E, Van Rie J, Lereclus D, Baum J, Dean DH. 1998. Revision of nomenclature for the Bacillus thuringiensis pesticidal crystal proteins. Microbiol Mol Biol Rev. 62(3): 807813.

Crickmore N, Baum J, Bravo A, Lereclus D, Narva K, Sampson K, Schnepf E, Sun M, Zeigler, DR. 2016. Bacillus thuringiensis toxin nomenclature. (http:// www.btnomenclature.info/); www.lifesci.sussex. ac.uk/home/Neil_Crickmore/Bt/holo2.html).

Dhingra H, Chaudhary K. 2011. Production of Bacillus thuringiensis $\mathrm{S}_{6}$ biomass using different cheap nitrogen sources. Acta Agric Serb. 16(31): 3-8.

Dregval OA, Cherevach NV, Andrienko OE, Vinnikov AI. 1999. The effect of a soil extract on the development of Bacillus thuringiensis on its synthesis of an insecticidal endotoxin. Mikrobiol Z. 61(4): 40-44.

Dregval OA, Cherevach NV, Vinnikov AI. 2002. Influence of composition of the nutrient medium on growth and development of entomopathogenic bacteria Bacillus thuringiensis. Mikrobiol Z. 64(2): 44-48.

Dulmage HT. 1971. Production of delta-endotoxin by eighteen isolates of Bacillus thuringiensis serotype 3 in fermentation media. J Invertebr Pathol. 18(3): 353358 .

Dulmage HT, Correa JA, MartinezAJ. 1970. Co-precipitation with Lactose as a means of recovering the sporecrystal complex of Bacillus thuringiensis. J Invertebr Pathol. 15(1): 15-20.

Entwistle PF, Cory JS, Bailey MJ, Higgs S. 1993. Bacillus thuringiensis: an environment biopesticide, theory and practice. Chichester: John Wiley \& Sons, USA. 193-220 pp.

Gujar GT, Kumari A, Kalia V, Chandrashekar K. 2000. Spatial and temporal variation in susceptibility of the American bollworm, Helicoverpa armigera (Hübner) to Bacillus thuringiensis var. kurstaki in India. Curr Sci India. 78(8): 995-1001.

Harish J. 2006. Development and evaluation of different formulations of Bacillus thuringiensis for management of Helicoverpa armigera. Ph.D. Dissertation, CCS Haryana Agriculture University, Hisar, India.

Hofte H, Whiteley HR. 1989. Insecticidal crystal proteins of Bacillus thuringiensis. Microbiol Rev. 53(2): 242255 .

Hwang DL, Yang WK, Foard DE, Lin KTD. 1978. Rapid release of protease inhibitors from soybeans. Plant Physiol. 61: 30-34.

Johnson V, Shah RN, Shah DN, Patel KA, Mehta MH. 1994. Production of Bacillus thuringiensis based bioinsecticide: Influence of various nitrogen sources on process economics, pp. 161-167, In: Proceedings, Microbes for better living: proceedings of MICONInternational-94 and $35^{\text {th }}$ Annual Conference of Association of Microbiologists of India, 9-12 November 1994, DFRL, Mysore, India.

Kalia V, Sethi T, Gujar GT. 2013. Susceptibility of Brinjal shoot and fruit borer, Leucinodes orbonalis (Guenee) to Bacillus thuringiensis and its Cry toxins. Biopestic Int. 9(1): 88-92.

Kumar A, Sra K, Sangodkar UMX, Sharma VP. 2000. Advances in the bio-control of mosquito vectors utilizing Bacillus sphaericus and Bacillus thuringiensis var. israelensis. Proceedings of National Academy of Science, India. 70(1): 1-20.

Khodair TA, Abdelhafez AAM, Sakr HM, Ibrahim MMM. 2008. Improvement of Bacillus thuringiensis bioin- 
secticide production by fed-batch culture on low cost effective medium. Res J Agric Biol Sci. 4(6): 923-935.

Laemmli UK. 1970. Cleavage of structural proteins during the assembly of the head of bacterioohage T4. Nature (Lond.) 227: 680-685.

Lu Q, Cao G-C, Zhang L-1, Liang G-M, Gao X-W, Zhang Y-J, Guo Y-Y. 2013. The binding characterization of Cry insecticidal proteins to the brush border membrane vesicles of Helicoverpa armigera, Spodoptera exigua, Spodoptera litura and Agrotis ipsilon. J Integr Agr. 12(9): 1598-1605.

Meena RK, Krishna kumara GG, Alpana, Gujar GT, Kaur S. 2012. Screening of Bacillus thuringiensis isolates recovered from diverse habitats in India for the presence of cry1A-type Genes and cloning of a cry $1 \mathrm{Ac} 33$ gene toxic to Helicoverpa armigera (American Bollworm). Asian J Biotechnol. 4(2): 53-69.

Moraes IO, Santana MHA, Hokka CO. 1981. The influence of oxygen concentration on microbial insecticide production. In: Proceedings of $8^{\text {th }}$ International Forum Symposium: Advances in Biotechnology. Vol 1, London, U.K. pp. 75-79.

Morris ON, Kanagaratnam P, Converse V. 1997. Suitability of 30 agricultural products and by-products as nutrient sources for laboratory production of Bacillus thuringiensis subsp. aizawai. J Invertebr Pathol. 70(2): 113-120.

Mummigatti SG, Raghunathan AN. 1990. Influence of media composition on the production of delta-endotoxin by Bacillus thuringiensis var. thuringiensis. $J$ Invertebr Pathol. 55(2): 147-151.

Navon A. 2000. Bacillus thuringiensis insecticides in crop protection- reality and prospects. Crop Prot. 19(8-10): 669-676.

Nester EW, Thomashow LS, Metz M, Gordon M. 2002. 100 years of Bacillus thuringiensis: a critical scientific assessment. American Society for Microbiology, Washington, DC. (http://academy.asm.org/images/ stories/documents/100yearsofbtcolor.pdf).

Oliveira HD, Sousa DOB, Oliveira JTA, Carlini CR, Oliveira HP, Pereira ML, Rocha RO, Morais JKS, Gomes-Filho E, Vasconcelos IM. 2010. Gm-Tx, a new toxic protein from soybean (Glycine max) seeds with potential for controlling insect pests. Process Biochem. 45: 634-640.
Poopathi S, Kumar KA. 2003. Novel fermentation media for production of Bacillus thuringiensis israelensis. $J$ Econ Entomol. 96(4): 1039-1044.

Prabakaran G, Balaraman K. 2006. Development of a costeffective medium for the large scale production of Bacillus thuringiensis var. israelensis. Biol Control. 36: 288-292.

Ramanujam B, Rangeshwaran R, Sivakmar G, Mohan M, Yandigeri MS. 2014. Management of insect pests by microorganisms. Proc Indian Natn Sci Acad. 80(2):455-471

Salama HS, Foda MS, Dulmage HT, Sharaby EL. 1983. Novel fermentation medium for production of -endotoxin from Bacillus thuringiensis. J Invertebr Pathol. 41(1): 8-19.

Sanchis V, Bourguet D. 2008. Bacillus thuringiensis: applications in agriculture and insect resistance management. A review. Agron Sustain Dev. 28(1): 11-20.

SAS Institute. 1998. SAS system for elementary statistical analysis surveys. For this research site, using the two technolo- SAS Institute Inc., Cary, NC.

Saravanan L, Gujar GT. 2006. Distribution of Bacillus thuringiensis Berliner in the samples of warehouse and cadavers. J Entomol Res (New Delhi). 30(1): 1-4.

Sarrafzadeh MH, Guiraud JP, Lagneau C, Gaven B, Carron A, Navarro JM. 2005. Growth, sporulation, deltaendotoxins synthesis, and toxicity during culture of $B$. thuringiensis H 14. Curr Microbiol. 51(2): 75-81.

Scherrer P, Lüthy P, Brüno T. 1973. Production of $\delta$-endotoxin by Bacillus thuringiensis as a function of glucose concentration. Appl Microbiol. 25(4): 644-646.

Schnepf E, Crickmore N, Van Rie J, Lereclus D, Baum J, Feitelson J, Zeigler DR, Dean DH. 1998. Bacillus thuringiensis and its pesticidal crystals proteins. Microbiol Mol Biol Rev. 62(3): 775-806.

Shojaaddini M, Moharramipour S, Khodabandeh M, Talebi AA. 2010. Development of a cost effective medium for production of Bacillus thuringiensis bio-insecticide using food barley. J Plant Prot Res. 50(1): 9-14.

Travers RS, Martin PAW, Reichelderfer CF. 1987. Selective process for efficient isolation of soil Bacillus spp. Appl Environ Microbiol. 53(6): 1263-1266. 
Valicente FH, Tuelher EDS, Leite MIS, Freire FL, Vieira CM. 2010. Production of Bacillus thuringiensis biopesticide using commercial lab medium and agricultural byproducts as nutrient sources. Revista Brasileira De Milho E Sorgo 9(1): 1-11.

Whalon ME, Mota-Sanchez D, Hollingworth RM. 2008. Global pesticide resistance in arthropods. CABI International, Wallingford, U.K.

Whalon ME, Mota-Sanchez D, Hollingworth RM. 2013. Arthropod Pesticide Resistance Database. (http:// www.pesticideresistance.com/index.php).

WHO [World Health Organization]. 1999. Microbial Pest Control Agent: Bacillus thuringiensis. Environment
Health Criterion 217, World Health Organization, Geneva.

Yadav K, Dhiman S, Baruah I, Singh L. 2011. Development of cost effective medium for production of Bacillus sphaericus strain isolated from Assam, India. Microbiol J. 1(2): 65-70.

Zouari N, Bensikali S, Jaoua S. 2002. Production of deltaendotoxins by Bacillus thuringiensis strains exhibiting various insecticidal activities towards Lepidoptera and Diptera in gruel and fish meal media. Enzyme Microbiol Technol. 31(4): 411-418. 